Redressing The Harms of Government (In)

Action: A Section 7 Versus Section 15 Charter Showdown

\section{Jennifer Koshan*}

\section{Introduction}

When considering the recent Charter claims of vulnerable individuals seeking to redress the harms of government action or inaction, there are two related trends in the appellate case law on sections 7 and 15 that merit attention. ${ }^{1}$ First, the Supreme Court has undertaken new approaches to equality rights under section 15(1) and 15(2) of the Charter, with a marked lack of success of claims in spite of (or perhaps because of) these approaches. The cases of Kapp, ${ }^{2}$ Withler, ${ }^{3}$ and Cunningham ${ }^{4}$ will be discussed in Part II as illustrations of this trend, along with cases where section 15 was given scant attention, such as Hutterian Brethren, ${ }^{5}$ AC $v$ Manitoba, ${ }^{6}$ and Fraser. $^{7}$ Second, there has been relative success of Charter claims under section 7 where there is strong evidence of harm to life, liberty or security of the person in circumstances where the government action was arbitrary, grossly disproportionate, or overbroad. In Part III, the cases of PHS Community Services, ${ }^{8}$ Adams, ${ }^{9}$ and Bedford ${ }^{10}$ will be shown to reflect this trend. ${ }^{11}$ These cases present an opportunity to discuss whether section 7 holds advantages over section 15 as a tool for disadvantaged persons challenging the harms of government (in)action, which will be addressed in Part IV. I conclude that while framing government harms as violations of life, liberty or security of the person may be a winning strategy for some Charter claimants, not all such harms can be presented in those terms, and the particular harms captured by section 15 must be given their due.

\section{Section 15 Equality Rights: New Approaches, Same Old Problems ${ }^{12}$}

a) Section 15(1): Equality and Discrimination

For many years the governing approach under section 15(1) was dictated by Law v Canada (Minister of Employment and Immigration), ${ }^{13}$ which established a three-step test for claims of discrimination that focused on whether the claimant could show a violation of their human dignity. Several contextual factors were relevant to this inquiry: (1) pre-existing disadvantage, stereotyping, prejudice, or vulnerability of the claimant; (2) the correspondence between the grounds on which the claim was based and the actual need, capacity, or circumstances of the claimant; (3) the ameliorative purpose or effects of the law upon a more disadvantaged person or group; and (4) the nature and scope of the interest affected by the law. ${ }^{14}$

The Law case was widely criticized for its mechanical, formalistic approach to section 15(1), the fact that some section 1 considerations 
had been imported into section 15, and the abstract, subjective nature of human dignity. These criticisms of Law were acknowledged by the Supreme Court in Kapp, ${ }^{15}$ where the Court purported to restate its commitment to substantive equality and revisited its approach to equality rights. ${ }^{16}$

Kapp involved the federal government's Aboriginal fishing strategy, which gave a 24 -hour priority licence to fishers from three First Nations on the Fraser River. A group of mostly non-Aboriginal commercial fishers argued that this priority violated their equality rights under section 15(1) of the Charter. In Kapp, the Court consolidated the test for discrimination into two steps: (1) Does the law or government action create a distinction based on enumerated / analogous grounds; and (2) Does the distinction create a disadvantage by perpetuating prejudice or stereotyping? ${ }^{17}$ It noted the continued relevance of Law's four contextual factors to this inquiry, suggesting that pre-existing disadvantage and the nature of the interest affected were relevant to the perpetuation of disadvantage and prejudice, while correspondence between the grounds and the actual need, capacity, or circumstances of the claimant pertained to stereotyping. The ameliorative purpose or effect of the law was now to be considered under section 15(2), although the Court left open the possibility that it might also be relevant to whether the law or program perpetuated disadvantage. ${ }^{18}$

More importantly, Kapp held that the question of whether there is discrimination should no longer be assessed through the lens of human dignity. Although this is a positive development given the problems with the Law approach, the definition of discrimination in Kapp was arguably narrowed through the Court's focus on stereotyping and prejudice, which fails to include other harms of discrimination such as marginalization, oppression, and deprivation of significant benefits. ${ }^{19}$ Kapp also provided scant guidance on how its new approach to section 15(1) should be applied. ${ }^{20}$

The next major section 15(1) decision of the Supreme Court was Withler. In this case, surviving spouses of federal employees challenged a reduction in supplementary death benefits they were entitled to receive upon death of their partners; the reduction was based on the age of the plan member at the time of death, grounding a claim of age-based discrimination. In a unanimous decision, the Court confirmed the Kapp test for discrimination and its focus on perpetuating prejudice or stereotyping. ${ }^{21}$ It also attempted to explain these terms. ${ }^{22}$ Government action perpetuates disadvantage when it treats historically disadvantaged groups in ways that exacerbate their situation..$^{23}$ Stereotyping occurs where government action imposes a disadvantage "based on a stereotype that does not correspond to the actual circumstances and characteristics" of the claimant. ${ }^{24}$ The Court noted that stereotyping may perpetuate prejudice and disadvantage, but a group that is not historically disadvantaged may also be subjected to discriminatory stereotyping. ${ }^{25}$

Withler reiterated the relevance of Law's four contextual factors, ${ }^{26}$ and appeared to add another. Where the impugned law is part of a larger benefit scheme, the ameliorative effect of the law on others and the interests it attempts to balance should also influence the discrimination analysis. ${ }^{27}$ Put another way, "[a]llocation of resources and particular policy goals that the legislature may be seeking to achieve" were said to be relevant in cases involving large benefit schemes. $^{28}$

Withler is also significant for the Court's approach to comparative analysis under section 15(1). Since Andrews, the Court has consistently argued that comparison is inherent in the concept of discrimination. ${ }^{29}$ The Court's approach to comparators often defeated equality claims, particularly when it focused on finding a group that mirrored the characteristics of the claimant. ${ }^{30}$ In Withler, the Court acknowledged the criticism of the mirror comparator approach, and how it may result in formal equality. It also noted how this approach may exclude intersecting grounds of discrimination, and may unfairly burden claimants by requiring evidence of differential treatment in relation to the perfect comparator. $^{31}$

In Withler, the Court called for a new, more flexible approach to comparison. If the claimant establishes a distinction based on a protected 
ground, the claim should proceed to the second step of the analysis, and there is no need to identify a particular comparator group. ${ }^{32}$ This will be "relatively straightforward" for claims of direct discrimination, but may be more difficult for claims of indirect discrimination, where the law is neutral on its face but has an adverse impact on a disadvantaged group. ${ }^{33}$ In these cases, the Court said that claimants "will have to more work to do," and should bring forward evidence of historical disadvantage to show how the law adversely treats them relative to others. ${ }^{34}$ At the second step, comparison may be of assistance in analyzing whether the government action perpetuates disadvantage or stereotyping. ${ }^{35}$

On the facts in Withler, the Court found that there was a distinction based on agedeath benefits were reduced for claimant spouses where their partners were over a particular age at the time of death, and step one of the Kapp test was satisfied without the need to identify a comparator group. ${ }^{36}$ However, the Court held that this distinction did not amount to discrimination under step two of the Kapp test. The "central consideration" was the overall purpose of the benefit scheme, and the allocation of government resources and legislative policy goals were also relevant factors. ${ }^{37}$ Comparing the claimants to the other beneficiaries in the broader scheme, the Court found that their reduced death benefits were not discriminatory, as they accounted for the claimants' actual needs and circumstances. ${ }^{38}$ While it was not a "perfect fit" for each beneficiary, the overall scheme balanced the needs of different plan members and their spouses through a broad scheme of benefits over time. ${ }^{39}$

Although the Court's approach to comparative analysis in Withler is potentially advantageous for equality rights claimants in its rejection of the mirror comparator approach, the addition of the fifth contextual factor in cases involving large benefit schemes reintroduces a problem from Law - the Court is importing section 1 considerations about government objectives into section 15(1). ${ }^{40}$ Another concern is the Court's statement that it will be more difficult to prove adverse effects discrimination claims. This is contrary to previous case law, ${ }^{41}$ and may make it more challenging for particular claimants where the inequalities they face flow from laws that fail to take their needs and circumstances into account. The Court's continued focus on prejudice and stereotyping rather than a broader range of harms of discrimination is also problematic. ${ }^{42}$ The evidence that it was elderly widows who were disadvantaged by the reduced death benefits was virtually ignored by the Court. ${ }^{43}$

There are also several recent cases where section 15(1) claims were summarily dismissed by the Court. ${ }^{44}$ For example, in Hutterian Brethren, the Court considered the constitutionality of the mandatory photo requirement for drivers' licences in Alberta in light of its impact on Hutterites who believed that having their photos taken was a violation of the second commandment. The case focused on religious freedom under section 2(a) of the Charter, but because the majority found the section 2(a) violation was justified under section 1, it went on to review the section 15 arguments. In very short order, the majority dismissed the section 15(1) claim, stating that any distinction "arises not from any demeaning stereotype but from a neutral and rationally defensible policy choice." ${ }^{\prime 5}$ The Court seemed to further narrow the definition of discrimination to include only stereotyping, and its reference to a "neutral" policy choice ignored adverse effects discrimination and included inappropriate section 1 considerations about the rationality of government policy. ${ }^{46}$

In $A C$ the Court quickly dismissed a section 15 claim of age discrimination in the context of competency to make medical decisions, focusing instead on sections 2(a) and 7 of the Charter. ${ }^{47}$ Writing for a plurality of justices, Abella $\mathrm{J}$ held that the ability of those under sixteen to make treatment decisions was "ultimately calibrated in accordance with maturity, not age, and no disadvantaging prejudice or stereotype based on age can be said to be engaged." ${ }^{8}$ In a concurring judgment, McLachlin CJC and Rothstein $\mathrm{J}$ found that the distinction between those under and over sixteen was "ameliorative, not invidious," ${ }^{39}$ suggesting that if a law treats a person adversely but for their own good, it will not be discriminatory. ${ }^{50}$ In dissent, Jus- 
tice Binnie found some support for the section 15(1) arguments, but ultimately stated that "the real gravamen of A.C.'s complaint is ... with the forced treatment of her body in violation of her religious convictions" rather than age discrimination. ${ }^{51}$

In Fraser, ${ }^{52}$ the Supreme Court considered the constitutionality of legislation that created a separate labour relations regime for farm workers. The challenge focused on freedom of association under section 2(d) of the Charter, but also claimed discrimination based on status as an agricultural worker. On the section 15(1) issue, the majority held that it had not been established that the impugned regime "utilizes unfair stereotypes or perpetuates existing prejudice and disadvantage," and that the claim was premature until the application of the legislation had been tested. ${ }^{53}$ In a concurring judgment, Justice Deschamps went further, finding that "economic inequality" is not protected under section 15 of the Charter. She also found that employment status and the category of "agricultural worker" were not analogous grounds under section 15(1). ${ }^{54}$

Section 15(1) was not the major issue in these cases, but they still give some sense of how difficult equality rights challenges can be under the current approach. The Court dismissed the section 15(1) arguments in only a few short paragraphs in each case without undertaking a full analysis and perpetuated Kapp's failure to give guidance to claimants and lower courts about how to mount and assess such claims in future cases. ${ }^{55}$ The cases also illustrate the $\mathrm{Su}$ preme Court's preference for deciding cases on other grounds where it has that option. This is not a new phenomenon, ${ }^{56}$ but it may discourage Charter claimants from focusing on section 15 where alternatives are available.

It is noteworthy that no equality rights claims including or since Kapp have been successful at the Supreme Court, even in dissenting judgments. ${ }^{57}$ This is not to say that all of these claims should have succeeded. In particular, the "reverse discrimination" claim in Kapp would not have promoted substantive equality if it had been accepted. ${ }^{58}$ On the whole, however, the application of the Kapp approach has not been positive for vulnerable groups seeking redress for the harms of government (in)action. ${ }^{59}$

\section{b) Section 15(2): Affirmative action}

The next developments on equality rights relate to section 15(2) of the Charter. In Kapp, the Supreme Court modified its previous approach, ${ }^{60}$ where section 15(2) was characterized as an interpretive aid to section 15(1), deciding that section 15(2) should have "independent force" in the section 15 analysis.$^{61}$ If a claimant proves a distinction made on an enumerated or analogous ground under the first step of section 15(1), the government has an opportunity to prove that the impugned law, program or activity is ameliorative under section 15(2). If so, the discrimination claim fails. ${ }^{62}$

To be protected under section 15(2), the program must have a genuine ameliorative or remedial purpose, although that need not be the sole objective of the program. Laws that preclude or punish behavior will not qualify as ameliorative. ${ }^{63}$ While the focus is on purpose rather than effects, it must be "plausible that the program may indeed advance the stated goal of combatting disadvantage." ${ }^{6}$ The program also must be aimed at a specific disadvantaged group, as section 15(2) is intended to protect targeted government programs rather than "broad societal legislation." ${ }^{65}$ The Court was careful to avoid suggesting that section 15(2) "saves" ameliorative laws, stating that laws that meet the requirements of section 15(2) are, by definition, not discriminatory as they aim to promote the equality of particular groups. ${ }^{66}$

Applying this test to the facts, the Court in Kapp found that there was a distinction based on race under the first step of section 15(1), as the claimant fishers did not have the same priority as the targeted Aboriginal fishers. ${ }^{67}$ However, the Aboriginal fishing strategy and the communal licence issued to the First Nations in question met the criteria for an ameliorative program under section 15(2); as such the claim of "reverse discrimination" was rejected. ${ }^{68}$

Kapp did not address how section 15(2) should be applied in cases where underinclusive benefit programs are at issue, i.e. where a disad- 
vantaged group claims discriminatory exclusion from an ameliorative program. The Supreme Court dealt with this issue in Cunningham. That case involved Métis persons who opted to register as status Indians to receive health benefits under the Indian Act. ${ }^{69}$ They then lost their status under Alberta's Metis Settlements Act, ${ }^{70}$ resulting in a loss of benefits including the right to vote in Métis Council elections and the right to reside on Métis lands. The claimants challenged the relevant sections of the MSA under sections 2(d), 7 and 15 of the Charter. ${ }^{71}$

In another unanimous judgment, Cunningham held that the Kapp approach to section 15(2) fully applies to underinclusive ameliorative programs. The Court noted that "it is unavoidable that ameliorative programs, in seeking to help one group, will necessarily exclude others,"72 and decided that governments can target particular disadvantaged groups as a matter of priority and leave other disadvantaged groups out of a program, even those persons who "share a similar history of disadvantage and marginalization." ${ }^{73}$ Moreover, exclusions that might otherwise be discriminatory are permitted if they "serve and advance" the object of the ameliorative program. ${ }^{74}$ This is an easier standard for the government to meet than in Kapp, which required that such distinctions be "necessary" to advance the program's goals. ${ }^{75}$ The Court also used the language of "saving" in Cunningham to describe the effect of section 15(2) on ameliorative programs, another extension of Kapp. ${ }^{76}$

Applying this approach, the Court construed the purpose of the MSA as "to enhance Métis identity, culture, and self-government through the establishment of a Métis land base," and found that this was an ameliorative purpose within the meaning of section $15(2){ }^{77}$ It followed that the exclusion of Métis persons with Indian status from membership in Métis settlements did "serve and advance" the object of preserving distinctive Métis status, and the exclusion was therefore protected under section 15(2). ${ }^{78}$ The Court overturned the finding of the Alberta Court of Appeal that the exclusion of some Métis from the MSA-including those with strong connections to Métis culture and identity-was arbitrary and not protected by section 15(2), and was indeed discriminatory under section 15(1). ${ }^{79}$ The Supreme Court did not even get to the question of the potentially discriminatory effects of the MSA on the claimants, including gender-based inequalities. ${ }^{80}$

The Supreme Court's deferential approach in Cunningham will make it difficult for members of disadvantaged groups to claim that they were wrongfully excluded from benefits targeted at others. ${ }^{81}$ Cunningham might be distinguished in future section 15 cases, as it dealt with "a special type of ameliorative program ... designed to enhance and preserve the identity, culture and self-governance of a constitutionally recognized group," 82 but if not, the decision is a major blow to claims of discriminatory underinclusion.

In summary, there have been significant changes to the Supreme Court's approach to section 15(1) and (2) recently, but in spite of the Court's acknowledgement of criticisms of earlier equality rights cases, and in spite of being presented with alternative approaches that take substantive equality more seriously, ${ }^{83}$ the Court is making it very difficult for claimants to prove discrimination even in cases where there is strong evidence of the harms of inequality.

\section{Section 7 Rights: Old Approaches, New Results}

Courts have indicated that the scope of section 7 of the Charter is unsettled and should be developed "cautiously and incrementally" ${ }^{84}$ However, recent cases involving section 7 have relied on well-established definitions of the rights to life, liberty and security of the person and the principles of fundamental justice, yet are making new ground in terms of how section 7 is being applied.

The leading case from the Supreme Court illustrating this trend is the unanimous decision in PHS Community Services Society. This case involved the Insite facility in the Downtown Eastside (DTES) of Vancouver, which provides safe injection services to intravenous drug users. Insite operated on the basis of an exemption from the Controlled Drugs and Substances 
Act. ${ }^{85}$ In 2008, the Minister responsible indicated that he would refuse to extend the exemption, ${ }^{86}$ and the claimants mounted a challenge based on section 7 of the Charter and federalism principles. ${ }^{87}$

Insite's clients were characterized by the Court as addicts with complex histories of abuse, drug use, and mental illness. The Court noted the demographics of drug users and their disadvantage in terms of age, homelessness, Aboriginality, and criminal histories, as well as the multiple harms to which injection drug addicts were vulnerable, harms typically caused not by the drugs themselves but by injection methods. ${ }^{88}$ According to the evidence, "Insite has saved lives and improved health ... without increasing the incidence of drug use and crime in the surrounding area." 89

The claimants argued that as applied to Insite, sections 4 and 5 of the CDSA, which prohibited possession and trafficking of controlled substances, were contrary to the section 7 rights to life, liberty and security of the person and the principles of fundamental justice, or in alternative, that the Minister's refusal to extend the exemption violated section 7 .

The Court first considered the right to liberty. It relied on the well accepted principle that liberty includes freedom from physical restraint, and is engaged when a law creates the threat of imprisonment..$^{90}$ The Court found that the CDSA prohibition of possession triggered the liberty interests of Insite staff, as their actions in allowing controlled substances within Insite's premises could result in potential imprisonment. ${ }^{91}$ The threat to the liberty of the staff was seen, in turn, to engage the section 7 interests of Insite's clients. If Insite's staff were unable to provide medical supervision and counselling for fear of criminal sanction, Insite's clients would be deprived of "potentially lifesaving medical care" and thus their rights to life and security of the person were implicated. ${ }^{92}$ Here again, the Court relied on well accepted definitions. Security of the person is violated when a law "creates a risk to health by preventing access to health care."93 Furthermore, "Where the law creates a risk not just to the health but also to the lives of the claimants, the deprivation is even clearer." ${ }^{94}$ It followed that the CDSA's prohibition on possession engaged the claimants' rights to life, liberty and security of the person more directly. ${ }^{95}$ The $C D S A$ 's prohibition against trafficking was not implicated on the facts of the case. ${ }^{96}$

Before moving to an analysis of the principles of fundamental justice, the Court considered the government's arguments about choice and lack of causation. The contention was that state action was not the cause of the harms to life, liberty and security of the person, rather these were matters related to the personal choices of the claimants. ${ }^{97}$ The Court rejected this argument, as the evidence established that addiction was a matter of illness rather than personal choice. $^{98}$

Under the principles of fundamental justice, the Court found that the availability of a ministerial exemption under the CDSA prevented the law itself from being arbitrary, grossly disproportionate or overbroad in light of its purposes - the protection of public health and the maintenance of public safety. ${ }^{99}$ However, the refusal of the Minister to grant an exemption under the CDSA did not comply with the principles of fundamental justice.

The test for arbitrariness is unsettled, ${ }^{100}$ and the Court did not take the opportunity to clarify it in PHS. Instead, it concluded that the Minister's decision was arbitrary regardless of the approach applied. ${ }^{101}$ This was so because the evidence demonstrated that criminal prohibitions had not reduced drug use in the DTES, yet drug users' risk of harm was reduced when they injected at Insite, and Insite had not resulted in increased crime rates, increased injections in public, or relapses amongst clients. ${ }^{102}$ Indeed, Insite had many favourable impacts, leading the Court to hold that the CDSA exemption furthered rather than undermined the objectives of public health and safety. ${ }^{103}$

As for gross disproportionality, the Court applied the test from Malmo-Levine, which asks whether "state actions or legislative responses to a problem ... are so extreme as to be disproportionate to any legitimate government interest."104 The evidence also led to the conclusion that the refusal of the exemption was grossly 
disproportionate-the loss of the proven benefits of Insite would be extreme compared to any benefit Canada might gain from refusing the exemption in terms of "presenting a uniform stance on the possession of narcotics." 105 In light of its findings on arbitrariness and gross disproportionality, the Court did not consider overbreadth. ${ }^{106}$

Section 1 could not save the Minister's arbitrary and grossly disproportionate refusal, ${ }^{107}$ and the Court proceeded to consider the appropriate remedy under section 24(1) of the Charter. It found that a declaration would be "inadequate" in light of the serious issues at stake, and ordered the Minister to grant an exemption to Insite under the CDSA forthwith. ${ }^{108}$ This remedy went further than the Court has been prepared to go in many previous cases involving unconstitutional government actions. ${ }^{109}$ However, the Court in PHS was clear that its order "does not fetter the Minister's discretion with respect to future applications for exemptions, whether for other premises, or for Insite." 110

PHS is an important example of how a compelling evidentiary record of harm that flows from state action can lead to the finding of a section 7 violation and a robust remedy. Are the media's accusations of "judicial activism" warranted in this case? ${ }^{111}$ The remedy in PHS places a positive obligation on the federal government to extend the exemption under the CDSA to Insite. However, it could also be seen as involving negative rights, as the government was in effect only ordered to refrain from prosecuting what would otherwise be criminal offences. PHS illustrates the problems with the positive / negative rights distinction, ${ }^{112}$ but it clearly does not create an obligation on governments to establish facilities similar to Insite. ${ }^{113}$ Claims of entitlement to particular health services have not met with much success under either section 7 or section 15 of the Charter. ${ }^{114}$ But even if PHS does not have influence in this regard, it is still a concrete victory for the rights of a particular vulnerable group under section 7 , albeit a limited one.

There are other appellate level decisions under section 7 of the Charter with positive outcomes for disadvantaged groups as well. One example that pre-dates PHS is Adams, involving the constitutionality of the City of Victoria's bylaws that prohibited persons from sleeping in public places using overhead protection such as tents, tarps, boxes or other structures. ${ }^{115}$ At both the BC Supreme Court and Court of Appeal, the bylaws were found to violate the rights of homeless persons under section 7 of the Charter, contrary to the principles of fundamental justice. The decisions turned on several important findings of fact. At the relevant time, there were far fewer shelter beds than homeless persons living in Victoria. Evidence also showed the demographic realties of homelessness in terms of mental illness, substance abuse, Aboriginality, youth, and domestic violence. ${ }^{116}$ Expert evidence indicated that the kind of overhead protection banned by the bylaw was necessary to protect people sleeping outside from the elements, and that without such protection they faced "significant risks" to life and health, including hypothermia and skin and respiratory infections. ${ }^{117}$

This evidence led to findings that the claimants' rights to life and security of the person had been violated. The right to life was defined to include "the ability to provide oneself with adequate shelter" and the right to security of the person engaged "the protection of physical and psychological integrity." 118 Both of these rights were violated by the City's ban on temporary shelters in parks. ${ }^{119}$ Furthermore, "creating shelter to protect oneself from the elements is a matter critical to an individual's dignity and independence," such that the state's interference with this process was also seen as a deprivation of liberty within the scope of section $7 .{ }^{120}$

Under the principles of fundamental justice, the BC Court of Appeal found that the bylaw was aimed at "maintaining the environmental, recreational and social benefits of urban parks" and that the City's evidence established the harm caused by the possible overuse of parks. A restriction on the use of parks was therefore connected to the objective of the bylaw and was not arbitrary. ${ }^{121}$ On the other hand, the Court of Appeal held that the City had overshot the mark by enacting an absolute ban on the erection of temporary shelters when narrower measures 
would have achieved the goal, such as requiring the overhead protection to be removed each morning or creating zones in sensitive park regions where sleeping was not permitted. ${ }^{122}$ This amounted to overbreadth, as the City used means that went further than necessary to accomplish its objective. ${ }^{123}$

Given the finding of overbreadth, the bylaws did not survive section 1 Charter scrutiny. The Court of Appeal granted a fairly narrow remedy, declaring the offending provisions "inoperative insofar and only insofar as they apply to prevent homeless people from erecting temporary overnight shelter in parks when the number of homeless people exceeds the number of available shelter beds in the City of Victoria." 124

As in PHS, the City and the BC government (an intervener) tried to forestall the claim in Adams at the outset, arguing that the bylaw was not the cause of the respondents' homelessness. This argument was rejected. The Court of Appeal noted that in previous cases such as Morgentaler and Rodriguez, the challenged state action was not solely responsible for the claimants' circumstances, but causation was nevertheless established. The issue was not whether state action caused the claimants' homelessness, but whether the bylaw "impair[ed] the ability of the homeless to address their need for adequate shelter." 125 The government's argument about choice was also rejected. Although there was evidence that a small number of homeless persons forgo shelters, it was concluded at trial that "hundreds of the homeless have no option but to sleep outside in the public spaces of the City." 126

Another point made in Adams was that there was no need to explore whether section 7 imposes a positive obligation on the state to provide adequate housing, since the alleged violation was the City's prohibition of certain activities and the impact of those prohibitions on homeless persons in Victoria. ${ }^{127}$ Although the Court of Appeal noted that its decision would, practically speaking, "require the City to take some action in response,"128 it did not find it necessary to consider the argument of an intervener, the Poverty and Human Rights Centre, that section 7 includes a right to the provision of adequate shelter. ${ }^{129}$

Adams is thus a victory under section 7 , but like $P H S$, a limited one. This is illustrated by a subsequent case, Johnston $v$ Victoria, ${ }^{130}$ where the Court of Appeal declined to find a breach of section 7 where a homeless person was prevented from erecting a shelter in a park during the daytime. The Court declared that there was insufficient evidence of a shortage of adequate daytime shelter for homeless persons in Victoria, and consequently, was not prepared to find a breach of the claimant's life, liberty or security of the person. ${ }^{131}$

The third case reflecting the section 7 trend is Bedford, which involved a Charter challenge under sections 2(b) and 7 by prostituted wom$\mathrm{en}^{132}$ in Ontario to three prohibitions under the Criminal Code, concerning bawdy houses, living off the avails of prostitution, and communicating for the purposes of prostitution. ${ }^{133}$ The claim included evidence from prostituted women, police officers, experts led by the claimants and government, government reports and evidence of prostitution laws in other countries. ${ }^{134}$

The courts easily found a violation of liberty based on the threat of imprisonment to those working as prostitutes. ${ }^{135}$ The Ontario Court of Appeal also recognized that liberty protects "the right to make personal choices that go to the core of personal autonomy," but the decision to engage in what the Court viewed as "a particular commercial activity" was not seen as the sort of choice that should be protected under this definition. ${ }^{136}$

As for security of the person, the Court of Appeal stated that the right "defies exhaustive definition," yet cited well-accepted case law establishing that it includes "preservation of one's physical safety and well-being." 137 Several findings of fact were then relevant to establishing a violation of security of the person. Prostituted women were found to be at a high risk of physical violence, particularly those working on the streets; this risk could be reduced by working indoors and in close proximity to others, screening clients, and using bodyguards and drivers; and the impugned provisions of the Criminal Code were seen to contribute to the 
risk of physical harm by criminalizing some of these methods. ${ }^{138}$ These facts also defeated the governments' causation argument. The Court of Appeal found that although there was not a direct connection between the law and the claimants' security of the person, the effect of the prohibitions was to increase their risk of harm, which was sufficient to establish causation. ${ }^{139}$

The Court of Appeal also rejected the governments' submission that the claim must fail because prostitution was a matter of personal choice, noting that this argument "implies that those who choose to engage in the sex trade are for that reason not worthy of the same constitutional protection." ${ }^{140}$ This holding arguably goes further than PHS and Adams, where the "choice" arguments were dismissed on the facts rather than as a matter of principle (although the notion that prostitution is a matter of choice could also be critiqued). ${ }^{141}$

Turning to the principles of fundamental justice, the Court considered arguments that the laws were arbitrary, overbroad, and grossly disproportionate. The Court reiterated the uncertainty in the case law on arbitrariness noted in PHS, and held that it was bound by the governing test from Rodriguez. ${ }^{142}$ It also found that while some recent cases had conflated gross disproportionality and overbreadth, it must apply the separate definitions of those terms accepted by the Supreme Court in previous cases. ${ }^{143}$

The Court then reviewed each of the impugned provisions for its compliance with the three relevant principles of fundamental justice. It held that the bawdy-house provision was not arbitrary, as it was not inconsistent with its objective of combating neighbourhood disorder and safeguarding public health and safety. ${ }^{144}$ However, the blanket prohibition on all bawdyhouses was overbroad and grossly disproportionate in light of its objective and effects. ${ }^{145}$ The provision could not be saved under section 1 of the Charter, and the Court struck the word "prostitution" from the definition of "common bawdy-house," suspending the remedy for twelve months. ${ }^{146}$

The prohibition against living off the avails of prostitution was found to have as its objective the prevention of exploitation of prostitutes by pimps. ${ }^{147}$ Similar to its holding on the bawdyhouse provision, the Court of Appeal decided that this provision was not arbitrary, but it was overbroad and grossly disproportionate in view of this objective. ${ }^{148}$ Again, this provision could not be saved, and the Court's remedy was to read in the words "in circumstances of exploitation" to properly narrow the prohibition. ${ }^{149}$

As for the communicating provision, the Court of Appeal found that it was not arbitrary or overbroad in light of its goal of eliminating social nuisance. ${ }^{150} \mathrm{~A}$ majority of the Court also rejected the argument that the provision was grossly disproportionate. ${ }^{151}$ Accordingly, the communicating provision did not violate section 7 of the Charter. ${ }^{152}$

Dissenting Justices MacPherson and Cronk disagreed with the majority's holding on the communicating provision, finding that it was grossly disproportionate to the objective of eliminating social nuisance. Invoking section 15 of the Charter, they indicated that equality values "require careful consideration of the adverse effects of the provision on disadvantaged groups." 153 Because it is overwhelmingly marginalized women who are prostituted, they found that their "pre-existing vulnerability exacerbates the security of the person infringement caused by the communicating provision" and that the effects of the provision were grossly disproportionate. ${ }^{154}$

Bedford stands with PHS and Adams as an illustration of how traditional approaches to section 7 can be applied in ways that aim to protect the interests of members of vulnerable groups where there is strong evidence of harm. It also demonstrates how a failure to consider equality rights does not allow the full range of harms at issue to be addressed. ${ }^{155}$ In Bedford, the Women's Coalition for the Abolition of Prostitution intervened to make equality-based arguments to the effect that the criminalization of prostitution should continue "for the purchase, but not the sale, of sex." 156 It is somewhat ironic that the consideration of equality rights actually led the dissent to propose further decriminalization than the majority. 


\section{The Showdown: Section 15 Versus Section 7}

The trends in section 15 and section 7 cases discussed in Parts II and III are not new. The failure of section 15 to promote equality has been decried for decades, and the idea that section 7 may provide a viable alternative for disadvantaged groups also has a history, both in the literature ${ }^{157}$ and in the jurisprudence. ${ }^{158}$ Nevertheless, the persistence of the trend is troubling given recent section 15 decisions that purport to reinvigorate substantive equality. ${ }^{159}$

It is telling that equality rights arguments were not mounted by the parties in PHS, Adams or Bedford (although such arguments were raised by interveners in two of the cases). ${ }^{160}$ All of these cases could be seen as examples of adverse effects discrimination-in $P H S$, the failure to renew the CDSA exemption adversely affected persons with addictions, which is a recognized disability; in Adams, the bylaws prohibiting overhead structures in parks adversely impacted homeless persons; and in Bedford, the prostitution provisions had a disproportionate effect on marginalized women that only some members of the Court recognized, and only in a limited way. Adverse impact claims have proven especially difficult for the courts, ${ }^{161}$ and may be even more difficult post-Withler. ${ }^{162}$ The claimants in Adams would have had the added challenge of arguing that homelessness should be protected as an analogous ground under section 15 of the Charter. ${ }^{163}$

At the same time, equality rights claims are being made in recent litigation involving vulnerable groups, such as the Downtown Eastside Sex Workers case, another challenge to the prostitution provisions at issue in Bedford. ${ }^{164}$ The Centre for Equality Rights in Accommodation has filed an application arguing that the federal and Ontario governments have obligations under sections 7 and 15 of the Charter "to implement effective national and provincial strategies to reduce and eventually eliminate homelessness and inadequate housing." 165 The Barbra Schlifer Clinic is challenging the federal government's repeal of the long-gun registry on the basis of its violations of women's security of the person and equality rights. ${ }^{166}$ And in Carter $v$ Canada $(A G)$, the BC Supreme Court recently held that the assisted suicide provisions of the Criminal Code violate section 15 of the Charter, as they adversely affect persons with disabilities. ${ }^{167}$

Yet there may continue to be advantages for vulnerable groups in prioritizing claims under section 7 of the Charter. Section 7 appears to be a more amenable site for raising arguments based on international human rights law and evidence of practices in other jurisdictions. ${ }^{168}$ Furthermore, as noted above, government arguments about choice and causation, a common tactic in Charter cases, have not found much purchase in section 7 cases. Causation arguments have also been rejected in section 15 cases such as Eldridge, where the Supreme Court dismissed the contention that the state should not have to pay for sign language interpretation because state action was not the cause of the claimants' deafness. ${ }^{169}$ On the other hand, government arguments about choice have had more success in section 15 cases, ${ }^{170}$ and it remains to be seen whether the more principled rejection of "choice" in Bedford will provide a response to such arguments in the future. Lastly, section 7 claims may be advantageous in their ability to survive scrutiny under section 1 of the Charter, ${ }^{171}$ although it is also rare for the few section 15 cases that actually get to section 1 to fail at that stage. ${ }^{172}$

It is also important to acknowledge that there have been significant losses under section 7, for example in Gosselin, where the harms of inadequate social assistance for young welfare recipients were unsuccessfully challenged under both sections 7 and 15 of the Charter. ${ }^{173}$ PHS and the other section 7 decisions discussed above might rejuvenate reconsideration of social and economic rights issues, but because they were framed as negative rights claims, their impact may be limited. ${ }^{174}$ At least in theory, section 15 may remain a stronger vehicle for pursuing the argument that once the government decides to provide a benefit, it cannot do so in a way that excludes vulnerable groups, ${ }^{175}$ although this is itself a limited conception of the role of the state in responding to disadvantage, and it may now be further limited by Cunningham for targeted 
benefit programs. The role of interveners in these kinds of cases will continue to be crucial in critiquing these jurisprudential limitations.

To the extent Charter claims have had more recent success under section 7 than section 15 , one might speculate that the courts see some harms (e.g. those relating to physical health and safety) as more significant and worthy of Charter protection than others (e.g. those relating to stereotyping, prejudice and broader forms of disadvantage). In those cases where the two kinds of harm overlap, claimants may be well advised to focus on section 7 arguments. ${ }^{176}$ However, section 7 will not always be relevant. More fundamentally, we must not lose sight of the obvious fact that section 15 protects against harms that are also constitutionally recognized, and are of a qualitatively different nature than those protected by section $7 .{ }^{177}$ The Supreme Court implicitly recognized this in the Downtown Eastside Sex Workers Society case, when upholding the public interest standing of the society to challenge prostitution-related prohibitions on equality rights grounds in spite of the Bedford litigation. ${ }^{178}$ Section 15 directly engages harms that flow from membership in disadvantaged groups, ${ }^{179}$ including the perpetuation of oppressive power relations, denial of access to basic goods, and diminishment of self-worth in addition to prejudice and stereotyping. ${ }^{180}$ These are no less significant than the harms protected under section 7. Canadian courts must give the harms of inequality the equal recognition and protection they are guaranteed under section 15 before they become perpetual losers in the Charter showdown.

\section{Notes}

* Associate Professor, Faculty of Law, University of Calgary.

1 Canadian Charter of Rights and Freedoms, Part I of the Constitution Act, 1982, being Schedule B to the Canada Act, 1982 (UK) 1982, c 11 [Charter].

$2 R v$ Kapp, [2008] 2 SCR 483, 2008 SCC 41 [Kapp, cited to SCC].

3 Withler $v$ Canada (AG), 2011 SCC 12, [2011] 1 SCR 396 [Withler, cited to SCC].

4 Alberta (Aboriginal Affairs and Northern Development) v Cunningham, 2011 SCC 37, [2011] 2 SCR 670 [Cunningham, cited to SCC].
Alberta $v$ Hutterian Brethren of Wilson Colony, 2009 SCC 37, [2009] 2 SCR 567 [Hutterian Brethren, cited to SCC]. AC v Manitoba (Director of Child and Family Services), 2009 SCC 30, [2009] 2 SCR 181 [AC, cited to SCC].

7 Ontario (AG) v Fraser, 2011 SCC 20, [2011] 2 SCR 3 [Fraser, cited to SCC].

8 Canada (AG) v PHS Community Services Society, 2011 SCC 44, [2011] 3 SCR 134 [PHS, cited to SCC].

9 Victoria (City) v Adams, 2008 BCSC 1363, aff'd 2009 BCCA 563 [Adams].

10 Bedford $v$ Canada (AG), 2010 ONSC 4264, aff'd 2012 ONCA 186, leave to appeal granted, 2012 CanLII 64742 [Bedford].

11 Section 7 claims in the purely criminal context that raise liberty issues alone are beyond the scope of this article.

12 The analysis in this section is based on a series of articles I co-authored with Jonnette Watson Hamilton. See Jonnette Watson Hamilton \& Jennifer Koshan, "Courting Confusion? Three Recent Alberta Cases on Equality Rights PostKapp” (2010) 47 Alta L Rev 927 [Hamilton \& Koshan, "Courting Confusion"]; Jennifer Koshan \&Jonnette Watson Hamilton, “Terrorism or Whatever': The Implications of Alberta $v$. Hutterian Brethren of Wilson Colony for Women's Equality and Social Justice," in Sanda Rodgers \& Sheila McIntyre, eds, The Supreme Court of Canada and Social Justice: Commitment, Retrenchment or Retreat (Markham: LexisNexisCanada, 2010) 221 [Koshan \& Hamilton, “Terrorism or Whatever"]; Jennifer Koshan \& Jonnette Watson Hamilton, "Meaningless Mantra: Substantive Equality after Withler" (2011) 16 Rev Const Stud 31 [Koshan \& Hamilton, "Meaningless Mantra"]; Jonnette Watson Hamilton and Jennifer Koshan, "The Supreme Court, Ameliorative Programs, and Disability: Not Getting It”, (2012) 25 CJWL [forthcoming][Hamilton \& Koshan, "Not Getting It"].

13 Law $v$ Canada (Minister of Employment and Immigration), [1999] 1 SCR 497 at para 88 (per Iacobucci, J) [Law].

14 Ibid.

15 Kapp, supra note 2 at para 22, McLachlin CJC and Abella J [citations omitted].

$16 \quad$ Ibid at paras 14-17.

17 Ibid at para 17.

18 Ibid at para 23. The Court's section 15(2) reasons will be discussed below in Part II(b).

19 See e.g. Hamilton \& Koshan, "Courting Confusion," supra note 12 at 937; Sophia Moreau, " $R$. 
v. Kapp: New Directions for Section 15" (20082009) 40 Ottawa L Rev 283 at 291-292. Hamilton \& Koshan, "Courting Confusion," ibid at $928-929$.

21 Withler, supra note 3 at para 30, McLachlin CJC and Abella J.

22 For a critique see, Koshan \& Hamilton, "Meaningless Mantra," supra note 12 at 48-49 (noting that the Court explains "perpetuation" rather than disadvantage, and that its definition of "stereotyping" is largely tautological).

30 Withler, supra note 3 at paras 48-49, citing Hodge $\checkmark$ Canada (Minister of Human Resources Development), 2004 SCC 65, [2004] 3 SCR 357 at paras $18,23$.

31 Withler, ibid at paras 55-59 [citations omitted].

32 Ibid at para 63.

33 Ibid at para 64.

34 Ibid.

35 Ibid at para 65.

$36 \quad$ Ibid at para 69.

$37 \quad$ Ibid at para 71.

38 Ibid at para 72-73.

39 Ibid at para 73, quoting Ryan JA's judgment in Withler, 2008 BCCA 539 at para 181.

40 Koshan \& Hamilton, "Meaningless Mantra," supra note 12 at 53-54.

41 See e.g. British Columbia (Public Service Employee Relations Commission) v BCGSEU, [1999] 3 SCR 3 (taking a unified approach to direct and adverse effects discrimination in the human rights context).

42 Koshan \& Hamilton, "Meaningless Mantra," supra note 12 at $48-49$.

43 Ibid at 56.

44 See also Daphne Gilbert, "The Silence of Section 15: Searching for Equality at the Supreme Court of Canada in 2007" (2008) 42 Sup Ct L Rev 497 (making the same observation for a number of cases before the Court in 2007).

45 Hutterian Brethren, supra note 5 at para 108, McLachlin, CJC. The dissenting justices (Abella, Fish and LeBel JJ) found that the violation of section 2(a) could not be justified under section 1 of the Charter and did not consider the section 15 claim.
46 See Koshan \& Hamilton, "Terrorism or Whatever," supra note 12 at 247-248.

47 AC v Manitoba, supra note 6. A majority dismissed the claims under sections 2(a) and 7 (Binnie, J. dissenting).

$48 \quad$ Ibid at para 111.

49 Ibid at para 152.

50 For a discussion of this tendency in earlier cases, see Dianne Pothier, "But It's for Your Own Good," in Margot Young, ed, Poverty: Rights, Social Citizenship, and Legal Activism (Vancouver: UBC Press, 2007) 40.

$51 \quad$ AC $v$ Manitoba, supra note 6 at para 231.

52 Fraser, supra note 7. The case was a follow up to Dunmore v Ontario (Attorney General), 2001 SCC 94, [2001] 3 SCR 1016, where the Court held that the complete exclusion of agricultural workers from labour relations legislation violated section 2(d).

53 Fraser, ibid at para 116, McLachlin CJC and LeBel J. Justice Abella dissented on the section 2(d) issue and did not consider section 15 of the Charter.

54 Ibid at paras 295, 315, Charron and Rothstein $\mathrm{JJ}$ concurring. In her concurring opinion in Dunmore, supra note 52 at paras 165-170, Justice L'Heureux Dubé found that the occupational status of agricultural workers qualified as an analogous ground.

55 See supra note 20 and accompanying text.

56 See for example Dunmore, supra note 52.

57 See also Ermineskin Indian Band and Nation v Canada, 2009 SCC 9, [2009] 1 SCR 222, where the Court rejected an argument of discrimination in the context of First Nations' property held in trust by the Crown.

58 See Hamilton \& Koshan, "Not Getting It," supra note 12 at notes 47-48 and accompanying text.

59 The Supreme Court's recent decision in Quebec (Attorney General) v A, 2013 SCC 5, suggests that a majority of the Court may be willing to soften its focus on prejudice and stereotyping as the markers of disadvantage, but its reference to "arbitrary disadvantage" also suggests that a government's objectives may continue to play a strong role under section 15(1) (see paras 325-331).

60 Lovelace v Ontario, [2000] 1 SCR 950, 2000 SCC 37. This equality rights claim, where non-status Indians and Métis persons sought access to a benefit scheme restricted to status Indians, was also unsuccessful.

61 Kapp, supra note 2 at para 40.

62 Ibid.

$63 I$ Ibid at paras 51, 54. This latter point was ignored in $A C v$ Manitoba, supra note 6 at 152, where a 
law denying minors the right to decide their own medical treatment was seen as ameliorative and not discriminatory (although under section 15(1), not section15(2)).

64 Kapp, ibid at para 48.

65 Ibid at para 55.

66 Ibid at para 40.

67 For a critique of the Court's finding of race-based discrimination, see e.g. June McCue, "Kapp's Distinctions: Race-Based Fisheries, the Limits of Affirmative Action for Aboriginal Peoples and Skirting Aboriginal People's Unique Constitutional Status Once Again" (2008) 5 Directions 56.

\section{note 12 at note 92 and accompanying text} (citing Women's Legal Education and Action Fund, Intervener Factum in Alberta (Minister of Aboriginal Affairs and Northern Development) v. Cunningham, online: LEAF <http://leaf.ca/ wordpress/wp-content/uploads/2011/03/Factum _ LEAF_Finale_Cunningham.pdf $>$ at para 19-21.

81 Hamilton \& Koshan, "Not Getting It," ibid at note 89 and accompanying text; Denise Réaume, "Equality Kapped: Alberta v. Cunningham" (2011), online: Women's Court of Canada, <http://womenscourt.ca/2011/07/ equality-kapped-alberta-v-cunningham/ $>$.

82 Cunningham, supra note 4 at para 54.

83 For example, in Cunningham, LEAF proposed a new approach to section 15(2) for cases of discriminatory underinclusion that would require full section 15(1) analysis. See LEAF Factum in Cunningham, supra note 80.
84 Chaoulliv Quebec (Attorney General), 2005 SCC 35, [2005] 1 SCR 791 at para 193, Binnie and LeBel, JJ dissenting; Gosselin v Québec (Attorney General), 2002 SCC 84, [2002] 4 SCR 429 at paras 79, 82, McLachlin, CJC. See also Margot Young, "Context, Choice and Rights: PHS Community Services Society v Canada (Attorney General)" (2011) 44 UBC L Rev 221 at 236-7 [Young].

85 Controlled Drugs and Substances Act, SC 1996, c 19 [CDSA].

86 The Court rejected the federal government's argument that the Minister had not yet made a decision to refuse a further exemption. PHS, supra note 8 at paras 119-125, McLachlin CJC. The federalism claim is beyond the scope of this article, but it was unsuccessful. See ibid at paras 50-73.

88 Ibid at paras 7-11.

89 Ibid at para 19.

90 Ibid at para 90, citing $R v$ Malmo-Levine, 2003 SCC 74, [2003] 3 SCR 571 at para 84. See also Re BC Motor Vehicle Act, [1985] 2 SCR 486 at para 23.

91 PHS, ibid at paras 86-90.

$92 \quad$ Ibid at para 91.

93 Ibid at para 93, citing e.g. $R v$ Morgentaler, [1988] 1 SCR 30 at 59, Dickson CJC and 105-6, Beetz J; Rodriguez v British Columbia (Attorney General), [1993] 3 SCR 519 at 589, Sopinka J; Chaoulli, supra note 84 at para 43 , Deschamps J. and paras 118-19, McLachlin CJC and Major J.

94 PHS, ibid at para 93.

95 Ibid at paras 92-93.

96 Ibid at paras $95-96$.

97 Ibid at paras 97-99.

98 Ibid at paras 99,101 . Young, supra note 84 at 248 252 , argues that while positive in its result, the finding that addiction is not a choice leaves the door open to dismiss future Charter challenges where the claimants might be viewed as acting out of personal choice.

99 PHS, ibid at paras 109-114.

100 In Chaoulli, supra note 84, the Court split on whether arbitrariness requires limits that are necessary to further the state objective (at paras 131-2) or should continue to be defined as in Rodriguez, supra note 93-i.e. whether "[a] deprivation of a right ... bears no relation to, or is inconsistent with, the state interest that lies behind the legislation" (Chaoulli at para 232).

101 PHS, supra note 8 at para 132.

102 Ibid at para 131.

103 Ibid.

104 Ibid at para 133, citing Malmo-Levine, supra note 90 at para 143. 
105 PHS, ibid at para 133.

106 Ibid at para 134.

107 Ibid at para 137.

108 Ibid at paras 147-150.

109 See e.g. Little Sisters Book and Art Emporium v Canada (Minister of Justice), 2000 SCC 69, [2000] 2 SCR 1120 at paras 157-158 (where the majority's remedy for Charter violations flowing from the discriminatory application of customs legislation was a declaration rather than injunction); Canada (Prime Minister) v Khadr, 2010 SCC 3, [2010] 1 SCR 44 at paras 39-47 (where the Court issued a declaration rather than order the federal government to request Khadr's repatriation to Canada).

110 PHS, supra note 8 at para 151.

111 See e.g. Kirk Makin, "Landmark Insite decision threatens peace between judges and legislators," Globe and Mail (11 October 2011), online: <http://www.theglobeandmail.com/ news/politics/landmark-insite-decision-threatens-peace-between-judges-and-legislators/ article557654/>.

112 For critiques of this distinction, see e.g. MarieEvve Sylvestre, "The Redistributive Potential of Section 7 of the Charter: Incorporating Socioeconomic Context in Criminal Law and in the Adjudication of Rights" (2010-12) 42 Ottawa L Rev 389 at 403; Margot Young, "Rights, the Homeless, and Social Change: Reflections on Victoria (City) v. Adams (BCSC)" (2009-10) 164 BC Studies 103 at 105-108; Cara Wilkie and Meryl Zisman Gary, "Positive and Negative Rights under the Charter: Closing the Divide to Advance Equality" (2011) 30 Windsor Rev Legal Soc Issues 37.

113 All levels of government initially supported the development of Insite (PHS, supra note 8 at para $1)$.

114 See e.g. Auton v British Columbia (AG), 2004 SCC 78, [2004] 3 SCR 657; Martha Jackman, "Health Care and Equality: Is There a Cure?” (2007) 15 Health LJ 87.

115 Parks Regulation Bylaw No 07-059, ss 13, 14, 16; Streets and Traffic Bylaw No 92-84, ss 73-74.

116 Adams (BCSC), supra note 9 at paras 44, 60, 61.

117 Ibid at paras 4, 67.

118 Ibid at paras 145, 149. The BCCA did not discuss the scope of the rights to life and security of the person.

119 Ibid, aff'd by BCCA at paras 102-110.

120 Ibid at para 148, aff'd (BCCA) at paras 104-110.

121 Adams (BCCA), ibid at paras 122-123.

122 Ibid at para 116.

123 Ibid at paras 112-116, citing $R v$ Heywood, [1994]
3 SCR 761 at 792-793 and $R v$ Demers, 2004 SCC 46, [2004] 2 SCR 489 at paras 37-43.

124 Adams (BCCA), ibid at para 166. The remedy at the BCSC was not similarly restricted.

125 Ibid at paras 87-89, quoting Adams (BCSC) at para 108.

126 Adams (BCSC), ibid at para 4, aff'd (BCCA) at paras 104-110.

127 Adams (BCSC), ibid at para 119, Adams (BCCA), ibid at paras 94-96. For critiques of Adams' reliance on and reinforcement of the positive / negative rights distinction, see e.g. Sylvestre, supra note 112 at 403, and Young, supra note 112 at 105-108. Adams (BCCA), supra note 9 at para 96.

129 Ibid at para 97.

130 Johnston $v$ Victoria (City), 2011 BCCA 400, aff'ing 2010 BCSC 1707.

131 Ibid at para 16. Sylvestre, supra note 112 at 404-405, argues that the narrow approach in Adams influenced this outcome.

132 Terminology in the context of prostitution is contentious; I use the term "prostituted women" rather than "prostitute" or "sex worker" to convey the typical vulnerability of women in this context. See also the Factum of the Intervener Women's Coalition in Bedford (ONCA); online: http://casac.ca/sites/default/files/Factum $\% 20$ -\%20Womens\%20Coalition.pdf [Factum of the Women's Coalition].

133 Criminal Code of Canada, RSC 1985, c C-46, sections 210, 212 and 213.

134 Bedford (ONCA), supra note 10 at paras 23-24.

135 Ibid at para 92; see also Bedford (ONSC) at para 281.

136 Bedford (ONCA), ibid at paras 93-94.

137 Bedford (ONCA), ibid at paras 97-99, citing Chaoulli, supra note 84; Morgentaler, supra note 93; and PHS, supra note 8.

138 Bedford (ONCA), ibid at para 100.

139 Ibid at paras 104-121, citing PHS, supra note 8.

140 Bedford (ONCA), ibid at para 123.

141 For a critique of the majority's focus on autonomy at the expense of equality, see Janine Benedet, "Violence Against Women: Trading Equality for Autonomy?" (Paper delivered at the Constitutional Law Symposium, Edmonton, 28 September 2012) [unpublished].

142 Bedford (ONCA), supra note 10 at paras 145-147.

143 Ibid at paras 150-155, citing Heywood, supra note 123; PHS, supra note 8; and Malmo-Levine, supra note 90.

144 Bedford (ONCA), ibid at paras 172-197.

145 Ibid at paras 198-204, 205-212.

146 Ibid at paras 214-218. 
147 Ibid at para 220.

148 Ibid at paras 240-254.

149 Ibid at para 278.

150 Ibid at paras 287-291.

151 Ibid at paras 315-316.

152 Ibid at para 324. The Court considered itself bound by Reference re ss 193 and 195.1(1)(c) of the Criminal Code, [1990] 1 SCR 1123, and did not consider whether the communicating provision unjustifiably violated section 2(b) of the Charter (ibid at para 86).

153 Bedford (ONCA), ibid at para 356.

154 Bedford (ONCA), ibid at para 358.

155 See Benedet, supra note 141.

156 Bedford (ONCA), supra note 10 at note 6; see also Factum of the Women's Coalition, supra note 132, paras 4, 19.

157 See e.g. Radha Jhappan, “The Equality Pit or the Rehabilitation of Justice" (1998) 10 CJWL 60. For more recent discussions, see Young, supra note 84; Sylvestre, supra note 112.

158 See e.g. Morgentaler, supra note 93; Rodriguez, supra note 93; New Brunswick (Minister of Health and Community Services) v G (J), [1999] 3 SCR 46 (involving the right to legal aid for child welfare proceedings).

159 See e.g. Kapp, supra note 2 at para 14.

160 In Adams, the Poverty and Human Rights Centre argued that section 7 should be interpreted consistently with the equality rights of the homeless (supra note 9 at para 57(BCCA)); in Bedford, the Women's Coalition for the Abolition of Prostitution intervened to make equality arguments; see above at note 156 and accompanying text.

161 For an exception see Eldridge $v$ British Columbia (Attorney General), [1997] 3 SCR 624.

162 See supra notes 33-34 and accompanying text.

163 Homelessness and poverty have not yet been recognized as analogous grounds under section 15. See e.g. $R v$ Banks, 2007 ONCA 19 at paras 98-100, leave to appeal refused, [2007] SCCR No 139. But see Falkinerv Ontario (Minister of Community and Social Services), 2002 CanLII 44902 (ONCA), (2002) 59 OR (3d) 481 (CA), where receipt of social assistance qualified as an analogous ground.

164 Canada (Attorney General) v Downtown Eastside Sex Workers United Against Violence Society, 2012 SCC 45 (finding public interest standing, thus allowing the substantive claim to proceed) [Downtown Eastside Sex Workers Society].

165 Tanudjaja et al $v$ Ontario and Canada, No CV10-403688 (On Sup Ct) (Notice of Application, filed 26 May 2010), online: The Social Rights Advocacy Centre, http://www.socialrights.ca/

litigation/homelessness/Notice\%20of\%20Application\%20Amended.pdf at 3. For a discussion see Sylvestre, supra note 112 at 406.

166

eral government's application to strike the Clinic's statement of claim was dismissed. See

Barbra Schlifer Commemorative Clinic v HMQ Canada, 2012 ONSC 5271.

1672012 BCSC 886 (finding a violation of section 7 of the Charter as well). See also the dissenting judgments in Rodriguez, supra note 93 (finding violations of sections 7 and 15).

168 See e.g. Adams, supra note 9 at paras 85-100 (BCSC), para 35 (BCCA) (considering international human rights protections of the right to shelter); Bedford (ONSC), supra note 10 at paras 185-213 (considering the regulation of prostitution in other jurisdictions).

169 Eldridge, supra note 161 at para 76.

170 See e.g. Diana Majury, "Women are Themselves to Blame: Choice as a Justification for Unequal Treatment" in Fay Faraday, Margaret Denike \& M Kate Stephenson, eds, Making Equality Rights Real: Securing Substantive Equality under the Charter (Toronto: Irwin Law, 2009) 209; Sonia Lawrence, "Choice, Equality and Tales of Racial Discrimination: Reading the Supreme Court on Section 15" in Sheila McIntyre \& Sanda Rodgers, eds, Diminishing Returns: Inequality and the Canadian Charter of Rights and Freedoms (Markham: LexisNexis Butterworths, 2006) 115. See also Quebec (Attorney General) v. A, supra note 59 (where a majority of the Court focused on choice as the basis for upholding the exclusion of de facto spouses from the spousal support provisions in Quebec's Civil Code).

171 Thanks to Eric Adams for raising this point.

172 For a rare section 15 case that failed at the section 1 stage, see Newfoundland (Treasury Board) $v$ NAPE, 2004 SCC 66, [2004] 3 SCR 381. Section 15 violations should arguably be as difficult to justify under section 1 as section 7 violations, given the internal limits in section 15 . See Jennifer Koshan, "Newfoundland (Treasury Board) v. NAPE (Women's Court of Canada)" (2006), 18 CJWL 327 at 354-5.

173 Gosselinv Quebec (Attorney General), [2002] 4 SCR 429, 2002 SCC 84. In other cases, the interests of vulnerable groups may preclude rather than ground successful section 7 claims. See e.g. Reference Re Section 293 of the Criminal Code of Canada, 2011 BCSC 1588 at paras 1182-83 (the Polygamy Reference).

174 See Sylvestre, supra note 112 at 404, and Young, supra note 112 at 111-12.

175 See e.g. Eldridge, supra note 161. 
176 For discussions of section 7 and justice-based rights as a strategic feminist alternative, see Jhappan, supra note 157; Kerri A Froc, "Constitutional Coalescence: Substantive Equality as a Principle of Fundamental Justice" (2010-12) 42 Ottawa L Rev 411.

177 See e.g. Sheilah Martin, "Balancing Individual Rights to Equality and Social Goals" (2001) 80 Can Bar Rev 299 at 329-30 (arguing that "human dignity" reduced section 15 to protecting harms already covered by section 7).

178 Downtown Eastside Sex Workers Society, supra note 164 at para 64 . Whether the ultimate decision in the case finds an equality rights violation is, of course, another matter.

179 See Dianne Pothier, "Connecting Grounds of Discrimination to Real People's Real Experience" (2001) 13 CJWL37.

180 Sophia Moreau, "The Wrongs of Unequal Treatment” (2004) 54 UTLJ 291. 